\title{
MUTU SENSORIK DAN NILAI-K IKAN CAKALANG (Katsuwonus pelamis. L) DARI INDUSTRI PENGOLAHAN IKAN ASAP DI MANADO
}

\author{
(Organoleptic Quality and K-Value of Skipjack Tuna, \\ from Smoked Fish Processing Industry in Manado)
}

Hens Onibala ${ }^{1}$

${ }^{1}$ Fakultas Perikanan dan Ilmu Kelautan Universitas Sam Ratulangi, Manado, Sulawesi Utara.

\begin{abstract}
Penelitian ini bertujuan untuk mengetahui kajian mutu sensorik dan tingkat kesegaran awardari ikan cakalang (Katsuwonus pelamis. L) yang digunakan sebagai bahan baku dalam pengolahan ikan asap di Manado. Ikan cakalang yang digunakan sebagai bahan baku memiliki nilai organoleptik rata - rata 7,79 dan nilai-K 37,08\%. Hal ini berarti bahwa bahan baku ikan cakalang yang digunakan pada industri pengolahan ikan asap tersebut pada umumnya menggunakan bahan baku ikan yang masuk dąlam tingkatan mutu III.
\end{abstract}

Kata kunci: cakalang, Katsuwonus pelamis. L, ikan asap, nilai-K, organoleptik

This objective of this research is to identifying the initial organoleptc quality and freshness level of skipjack tuna, Katsuwonus pelamis. L, used as raw materials forsmoked fish in Manado, North Sulawesi. Results found that skipjack tuna used as raw materials for smoked fish has an average organoleptic value of 7.79 and $\mathrm{K}$-value of $37.08 \%$. It means that the raw materials of the skipjack used in the smoked fish processing industry come from the fish of class III quality.

Keywords: skipjack tuna, Katsuwonus pelamis. L, smokedfish, K-value, organoleptic.

\section{PENDAHULUAN}

Masyarakat Indonesia telah menyadar bahwa ikan merupakan sumber protein dangizi yang penting bagi pertumbuhan serta kesêhatan (Anonimous, 1999), akan tetapi mengingat sifat ikan yang mudah membusuk, maka perlu dilakukan usaha pencegahan berupa pengawetan dan pengolahan. Pengawetan bahan pangan merupakan upaya untuk meningkatkan masa simpan, sedangkan pengolahan adalah salah satu cara untuk merubah bentuk menjadi bermacam-macam produk (Ilyas, 1972).

Adapun masalah yang timbul dari industri pengolahan ikan asap adalah sering beredarnya ikan asa p yang bermutu kurang baik di pasaran tradistenal, maupun supermarket di Manado. Berdasarkan permasalahan di atas, maka perlu dilakukan penelitian yang kaitannya dengan kondisi bahan baku pra-olah di industri pengolahan ikan asap.

Tujuan penelitian ini adalah untuk mengkaji mutu sensorik dan tingkat kesegaran awal dari ikan Cakalang (Katsuwonus pelamis. L) yang digunakan sebagai bahan baku dalam pengolahan ikan asap di Manado.

\section{METODE PENELITIAN}

Sampel yang digunakan dalam penelitian ini adalah Ikan Cakalang sebagai bahan baku dari industri pengolahan ikan asap yang ada di Sindulang, Manado. Sampel diambil secara acak sebanyak 3 kali, setiap sampel 10 ekor ikan dengan berat $2-2,5 \mathrm{~kg}$ dan selanjutnya dimasukkan ke dalam cool box yang telah dilapisi es dengan perbandingan 1:1. Sampel dibawa ke laboratorium penanganan dan pengolahan hasil perikanan Fakultas Perikanan dan Ilmu Kelautan Unsrat untuk dianalisa. Untuk mengkaji mutu sensorik dan tingkat kesegaran awal dari ikan Cakalang sebelum pengolahan dilakukan pengujian sebagai berikut:

\section{Uji Organoleptik}

Uji organoleptik adalah untuk mengkaji mutu sensorik awal dari bahan baku yang digunakan yang meliputi deskripsi mata, insang, lendir di permukaan, tekstur dan bau. Penilaian organoleptik ini menggunakan tim panel semi terlatih sebanyak 15 orang.

Dalam keadaan utuh sampel ikan disajikan sesudah diberi nomor kode. Panelis diminta untuk menilai kesan umum berdasarkan kriteria 
dan angka yang disediakan dalam bentuk score sheet organoleptik (Soekarto, 1985).

\section{Uji Nilai-K}

Pengujian nilai-K bertujuan untuk mengetahui tingkat kesegaran awal dari bahan baku yang digunakan sebelum proses pengolahan. Prosedur kerja pengujian nilai-K berdasarkan (Suwetja, 1993), yang terdiri dari:

1. Penyediaan bahan reaksi.

2. Pengaktifan resin penukar ion.

3. Penyediaan kolom penyediaan larutan standar:

a. Diambil $5 \mathrm{mg}$ inosin, kemudian dilarutkan dalam $10 \mathrm{ml}$ air suling bebas ion.

b. Diambil 2 mg IMP, kemudian dilarutkan dalam $10 \mathrm{ml}$ air suling bebas ion.

c. $2 \mathrm{ml}$ larutan inosin dialirkan ke dalam kolom yang berisi resin kemudian dielusikan dengan larutan A menjadi $50 \mathrm{ml}$ ditampung kemudian dibaca optikal densitasnya pada panjang gelombang $250 \mathrm{~nm}$. Selanjutnya $2 \mathrm{ml}$ inosin yang tidak dialirkan ke dalam resin ditambahkan $48 \mathrm{ml}$ larutan A kemudian dibaca optikal densitasnya pada panjang gelombang yang sama.

d. Perhitungan persentase rekoverinya adalah nilai absorbansi inosin yang dialirkan pada resin dibagi dengan nilai absorbansi inosin yang tidak dialirkan dikalikan $100 \%$.

e. Perlakuan yang sama dilakukan pada larutan IMP standar, hanya larutan pengelusíyang digunakan adalah larutan B.

4. Penyiapan larutan ekstraksi sampen $\mathrm{HClO}_{4}$.

Contoh daging diambil dari bagian punggung, kemudian dicacah atau dihaluskan dalam mortar yang dingin. Diambil sebanyak 5 gr, diekstrak dengan $20 \mathrm{ml} \mathrm{Hcl0} 4 \mathrm{Y}_{4} \%$. Setelah itu disentrifus selama 3 menit dengan kecepatan $3000 \mathrm{rpm}$. Supernatan yang dihasilkan ditampung dalam getas ukur. Residu yang ada dicuci dengan 20 nil $\mathrm{HclO}_{4} 5 \%$ kemudian disentrifus selama 3 menit dengan kecepatan $3000 \mathrm{rpm}$. Supernatan yang dihasilkan digabungkan dengan supernatan yang dihasilkan sebelumnya. Supetnatan ini kemudian dinetralkan dengan $\mathrm{KOH} 10 \mathrm{M}$ dan $1 \mathrm{M}$ (pH 6,4-6,8). Ekstrak yang telah dinetralisasi, disentrifus selama 3 menit dengan kecepatan $3000 \mathrm{rpm}$. Supernatan yang terbentuk ditampung dan residunya dicuci dengan $10 \mathrm{ml} \mathrm{HclO}_{4} 5 \%$ netral. Supernatan dan hasil pencucian ini digabungkan dengan supernatan sebelumnya. Selanjutnya larutan ekstraksi tersebut ditambahkan $\mathrm{NH}_{4} \mathrm{OH} 25 \%$ sehingga pH-nya menjadi 9,4.
5. Pemisahan Nukleotida dan Nukleosida Sebanyak $2 \mathrm{ml}$ larutan ekstraksi dipipetkan ke dalam kolom kemudian dielusikan dengan 50 ml larutan A $(0,002 \mathrm{M} \mathrm{HCl})$ ke dalam kolom yang berisi resin. Eluennya ditampung sampai menjadi $50 \mathrm{ml}$. Yang terelusi adalah inosin dan hipoksantin dan absorbansinya dibaca pada spektrofotometer dengan panjang gelombang $250 \mathrm{~nm}$. Kemudian $50 \mathrm{ml}$ larutan B $(0,02 \mathrm{M}$ $\mathrm{HCl}+0,6 \mathrm{M} \mathrm{NaCl})$ dialirkan ke dalam kolom yang berisi resin. Larutan pengelusi ditampung dimana terelusi adalah ATP + ADP + AMP + IMP, absorbansinya dibaca pada spektrofotómeter dengan panjang gelombang $2,50 \mathrm{~nm}$.

Metode pengujian kesegaran ikan dengan penentuan nilai-K adalah metode sederhana hasilnya bisa cepat diperoleh dan dapat dipercaya. Dalam penelitian ini pengujran nilai-K dapat dijelaskan dengan rumus berikut:

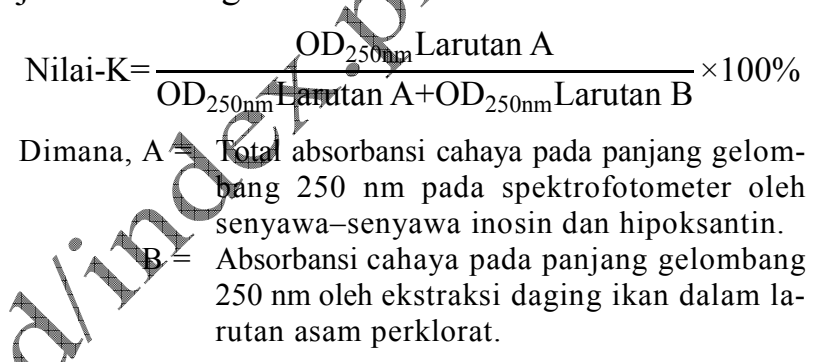

\section{HASIL PENELITIAN}

Hasil penilaian organoleptik ikan Cakalang yang meliputi mata, insang, lendir, tekstur dan bau diperoleh nilai rata-rata dari setiap karakteristik mutu yang disajikan pada Gambar 1 .

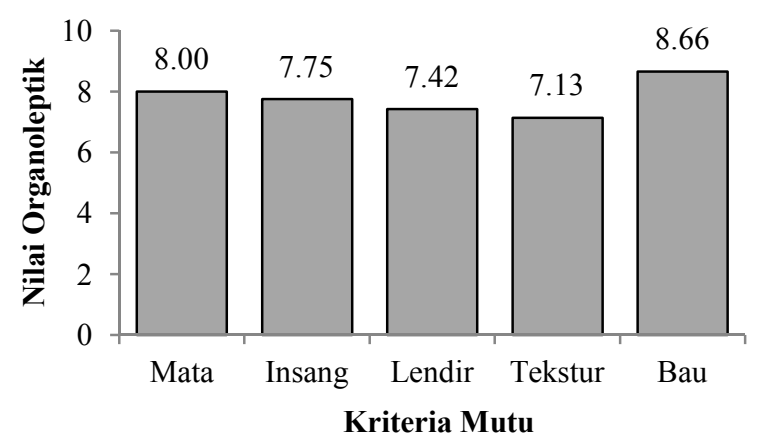

Gambar 1. Rata-rata penilaian organoleptik dari ikan Cakalang (Katsuwonus pelamis. L) segar dari industri pengolahan ikan asap di Sindulang.

Figure 1. The average value of organoleptic assessment of fish Cakalang (Katsuwonus pelamis. L) fresh from the smoked fish processing industry in Sindulang.

Berdasarkan hasil di atas, nilai rata-rata untuk mata, insang, lendir, tekstur, dan bau secara berturut menunjukkan bahwa bola mata masih ce- 
rah walaupun tidak cekung dengan kornea masih jernih. Sedangkan insang menunjukkan warna merah kurang cemerlang, agak berlendir dan bau mulai terasa asam. Untuk lendir di permukaan kulit ikan tampak mulai keruh agak putih susu dan kecerahan mulai suram. Daging ikan sampel memiliki tekstur agak lunak tetapi belum ada bekas jari bila ditekan. Sedangkan untuk bau ikan masih terasa segar atau tidak berbau.

Perbedaan karakteristik mutu ikan Cakalang berdasarkan uji organoleptik (Gambar.1), disebabkan oleh dua faktor yang pertama adalah para pengolah sengaja membeli bahan baku yang bermutu kurang baik karena harga yang relatif lebih murah, dan faktor yang lain adalah masih kurangnya pengetahuan para pengolah tentang penanganan ikan yang baik sebelum pengolahan.

Pengujian tingkat kesegaran ikan melalui penentuan nilai-K telah digunakan resin yang keaktifannya diuji dengan menghitung presentase recovery dari larutan standar inosin dan IMP. Hasil perhitungan persentase recovery yang didasarkan pada spektrofotometer varians DMS 100s dapat dilihat tabel 1 berikut.

Tabel 1. Presentase recovery dari larutan standar inosin dan IMP

Table 1. Percentage recovery of standard solution inosine and IMP.

\begin{tabular}{cccc}
\hline Standar & Dielusikan & Tidak Dielusikan & \% Recovery \\
\hline Inosin & 3.213 & 3.362 & 95.47 \\
IMP & 2.723 & 2.835 & 96.04 \\
\hline
\end{tabular}

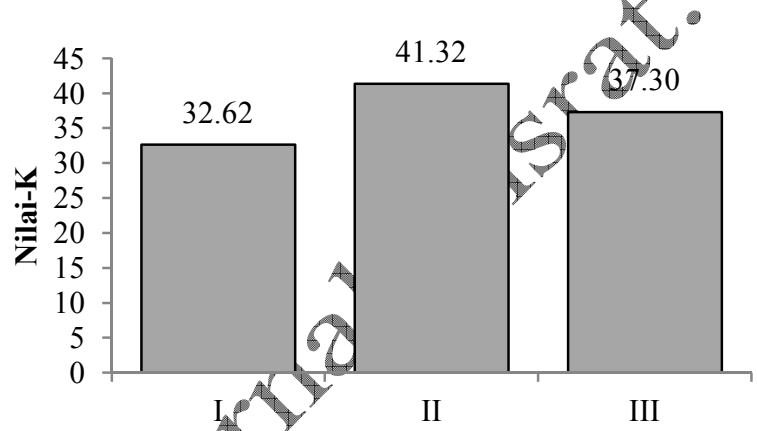

Sampel

Gambar2. Rata-rata nilai-K dari ikan Cakalang (Katsuwonus pelamis. L) segar dari industri pengolahan ikan asap di Sindulang.

Figure 2. The average $K$-value of fish Cakalang (Katsuwonus pelamis. L) fresh from the smoked fish processing industry in Sindulang.

Dari tabel 1 di atas dapat dilihat bahwa persentase recovery berkisar antara 95,56-96,04\%, hal ini dapat dijadikan standar untuk menyatakan bahwa resin yang digunakan dalam pengujian sam- pel ini sudah aktif. Suwetja (1993), menyatakan bahwa persentase recovery yang baik untuk inosin dan IMP berkisar antara 95-100\%, ini berarti resin yang telah diaktifkan dapat digunakan untuk pengujian sampel. Nilai-K ikan Cakalang dari industri dan dapat dilihat pada Gambar 2.

Rata-rata nilai-K ikan Cakalang pada pengambilan pertama $32,62 \%(\mathrm{Sd} \pm 0,26)$, pengambilan kedua $41,33 \%(\mathrm{Sd} \pm 0,13)$ dan pengambilan ketiga $37,30 \%(\mathrm{Sd} \pm 0,20)$, yang memilikinnilai rata-rata 37,10. Menurut Sikorski (1989) kelas mutu I memiliki kualitas sangat baik rata-rata nilar-K 3,5\% dan kelas mutu II yang berkualitas baik ratarata nilai-K 18,7\%. sedangkan menurut Echiyama et al. (1970) dalam Suwetja (1993), nilai-K ikan yang diuji segera setelah ikan matiadalah di bawah $5 \%$, rata-rata nilai-K ikan yangltelah diuji segera setelah ikan didaratkan di pelabuhan perikanan adalah $22,5 \%$.

Nilai-K yang didapat dari hasil analisis berkisar antara 32,62-41,37\%, masih bisa diterima/ dikonsumsi. Hal ini didukung oleh Suwetja (1990) yang menfatakan bahwa batas nilai-K untuk ikan sebagai bahan baku dan untuk pengolahan adalah $50 \%$, ang telah dikorelasikan dengan uji organoleptikedan uji TVB.

Perbedaan rata-rata nilai-K dan nilai organoleptik (mata, insang, lendir di permukaan kulit dan tekstur) ikan Cakalang dari 3 kali pengambilan selain disebabkan adanya penanganan yang berbeda dari setiap pengambilan juga dapat dipengaruhi oleh lamanya penyimpanan.

Menurut Nasran (1989), faktor yang mempengaruhi kesegaran ikan yaitu faktor intern dan faktor ekstern. Faktor intern meliputi jenis ikan, umur, makanan, kematangan gonad, kadar lemak, dan cara kematian ikan. Sedangkan faktor ekstern mencakup kondisi lingkungan seperti suhu, musim, jenis makanan yang tersedia dan perlakuan penanganan pada ikan.

\section{KESIMPULAN}

Dari hasil penelitian ini dapat ditarik kesimpulan bahwa mutu sensorik awal ikan Cakalang (Katsuwonus pelamis. L) segar dan nilai-K yang diperoleh dari industri pengolahan ikan asap di Sindulang-Tuminting, termasuk dalam kelas mutu III. Ikan Cakalang yang digunakan sebagai bahan baku pengolahan ikan asap ini masih dapat diolah sebagai ikan cakalang asap. 


\section{DAFTAR PUSTAKA}

Anonimous. 1999. Investasi Agribisnis Komoditas Unggulan Perikanan. Badan Agribisnis Departemen Pertanian. Penerbit Kanisius. Yogyakarta.

Ilyas, S. 1972. Pengantar Pengolahan Ikan. Lembaga Teknologi Perikanan. Jakarta.

Nasran, S. 1989. Masalah Mutu Kesegaran Ikan Tuna dan Diversifikasi Pengolahannya. Makalah Lokakarya Perikanan Tuna. Wartamina.
Sikorski, Z.E. 1989. Seafood : Resources, Nutritional Composition, and Preservation. CRC Press, Inc. Boca Ratom. Florida.

Soekarto, S. 1985. Penilaian Organoleptik Untuk Industri Pangan dan Hasil Pertanian. Bhatara Karya Aksara. Jakarta.

Suwetja, I.K. 1990. Penentuan Kesegaran Beberapa Jenis Ikan dengan HPLC. Jurnal Fakultas Perikanan. Vol I. No. 3. Hal 262-263. UNSRAT. Manado.

Suwetja, I.K. 1993. Metode Penentuan Mutu Ikan. Penentuan Kesegaran Jilid I. Fakultas Perikanan. UNSRAT. Manado.

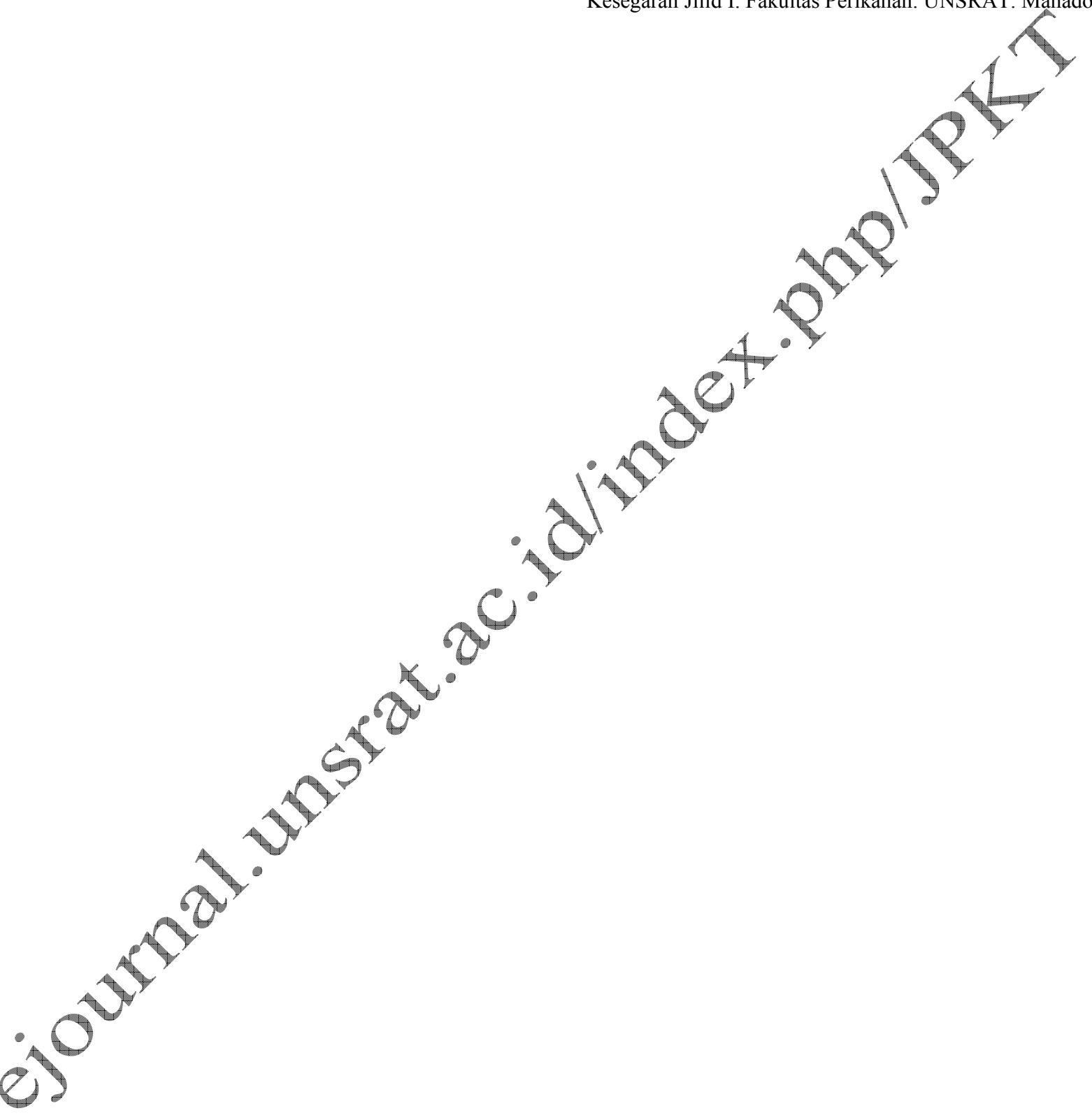

